\title{
When ideal and real culture clash - trust, infidelity and condom use
}

\author{
L Ackermann, (M.Soc.Sc), Department of Sociology, University of the Free State \\ GW de Klerk, (D.Phill), Department of Sociology, University of the Free State
}

\section{Abstract}

With high rates of HIV transmission in South Africa, the correct and consistent use of condoms has become critically important. The findings reported in this article form part of a larger study that investigated the vulnerability of women to HIV infection. This article concentrates on one dimension of the study: how a clash between real and ideal culture negatively impacts upon condom use. This study, conducted in Bloemfontein, revealed that an ideal culture of trust, resulted in non condom use. On the other hand, this study also revealed that despite the emphasis on an ideal culture of trust, a real culture of infidelity exists. This places individuals at risk of contracting HIV, as condom use is guided by ideal rather than real culture.

\section{Opsomming}

Met die hoë koers van MIV-oordrag in Suid-Afrika, is die korrekte en konsekwente gebruik van kondome van kardinale belang. Die bevindinge wat in hierdie artikel gerapporteer word, vorm deel van 'n groter studie waarin die vatbaarheid van veral vroue vir MIV-infeksie ondersoek is. Hierdie artikel fokus op die teenstellende dimensie van werklike en ideale kultuur wat negatief in kondoomgebruik manifesteer. In die studie, wat in Bloemfontein onderneem is, is bevind dat 'n ideale kultuur van vertroue tot gevolg het dat respondente nie sondermeer kondome gebruik nie. Hierdie studie het egter ook bevind dat, ten spyte van die beklemtoning van 'n ideale kultuur van getrouheid, 'n werklike kultuur van ontrou bestaan. Dit maak mense vatbaar vir MIV-infeksie omdat die besluit om kondome te gebruik, eerder deur ideale, as werklike kultuur, gerig word.

\section{Introduction}

South Africa, like many other Sub-Saharan countries, has a high rate of sexually transmitted infections including the $\mathrm{Hu}$ man Immunodeficiency Virus (HIV) (Key, De Noon \& Boyles, 1997:12). One of the strategies to prevent sexually transmitted infections (STI's), HIV in particular, is the correct and consistent use of condoms. However, condoms are not always used effectively and consistently and has lead many researchers to investigate this issue (De Wet, Ackermann \& Crichton., 2001; Warren, 1997; Pesa, Syre, \& Fu, 1999).

The findings reported in this article formed part of a larger study that investigated the vulnerability of women to HIV infection. This article concentrates on one dimension of the study: how a clash between real and ideal culture negatively impacts upon condom use.

\section{Methodology}

The general aim of this study was to explore the underlying dynamics that make women vulnerable to HIV infection. The study was undertaken in Bloemfontein', within a sample of HIV positive women. The participants in the study were selected by means of purposive (non-probability) sampling. In a study of this nature this type of sampling is really the only sampling option open to the researcher. Babbie (1993:204) states in this regard that there are situations where it would be either impossible or unfeasible to select probability samples. Neuman (1997:206) asserts that “ [p]urposive sampling is an acceptable kind of sampling for special situations. It uses the judgement of an expert in selecting cases or it selects cases with a specific purpose in mind. With purposive sampling, the researcher never knows whether the cases selected represent the population. It is used in exploratory research or in field research." Due to the fact that the entire population of HIV positive women is unknown and also because of the sensitive nature of the study the only option available to the researcher was that of purposive sampling. An expert was used (in this case, the same person who acted as the interviewer) to identify the "sample".

The sample included ten women. The ages of the participants ranged from 19 to 46 . The home languages of the participants were one of the following: Sesotho, isiXhosa, Setswana and English $^{2}$. Two of the participants were married, one was divorced and the rest were single or cohabiting. Only two of the participants were employed by a business, one was self employed and the rest described themselves as unemployed.

A qualitative approach was followed and in-depth semi-structured interviews were used to gather information. These interviews were tape recorded and later transcribed and translated into English. The researcher analysed the data by organising it into categories on the basis of themes, concepts or similar features.

${ }^{1}$ Bloemfontein is a city in the Free State Province of South Africa.

${ }^{2}$ One woman came from Zambia, but did not specify what her home language was, she participated in English. 


\section{Ethical considerations}

It is every social scientist's ethical responsibility to ensure that the participants in his/her study are not harmed in any way. This is particularly true in research involving HIV positive people. In order to protect the participants in this study the researcher used the Human Sciences Research Council's (HSRC) code of ethics as a guideline when conducting the research. The following principles of the HSRC (1997) were adhered to:

Informed consent

The participants right to refuse to participate in the study and their right to withdraw their participation at any stage. Confidentiality

\section{Conceptualising ideal and real culture}

Human beings are born into a complex culture which includes the knowledge, beliefs, customs, norms and values shared by members of a society. Culture has been defined as the way of life of members of a society (Giddens, 1993:31). Culture becomes so familiar to human beings, that it is taken for granted, and people do not question what they do or even why they do it. Everyday life is a reality that rarely requires explanation. Social life would be chaotic, if not impossible, if it were not so. Individuals learn a great number of cultural expectations from birth. These expectations or norms constitute the fundamental social rules in accordance with which persons normally act. Norms are defined as expectations of how one should act, behave and even feel in certain situations (Popenoe, 1995:58). Norms are situation bound, and vary according to the position and role that is relevant. Cultural expectations underlie almost every facet of daily interaction with others, and gives structure to our daily social lives. The behaviour of individuals is thus guided by the expectations of others and what they believe is right or wrong.

The argument used in this article hinges on two important concepts related to culture: ideal and real culture. Ideal and real culture can be seen as the difference between what people believe and what they actually do (Popenoe, 1995:65). Shepard, (2002:75) describes ideal and real culture as follows " $t]$ here is sometimes a gap between cultural guidelines and actual behaviour. This gap is captured in the concepts of ideal and real culture. Ideal culture refers to cultural guidelines publicly embraced by members of society; these are the guidelines we claim to accept. Real culture refers to actual behavior patterns."

At times ideal and real culture are consistent and what people actually do, corresponds with what the ideal value is. On the other hand, sometimes ideal and real culture clash - this is when people publicly embrace a certain norm/value but in reality practice something different. "For example, one aspect of America's ideal culture is honesty. Yet, in real culture some taxpayers annually violate the ... tax laws, .... some students cheat on exams ...... These are not isolated instances. These real cultural patterns are often passed from generation to gen- cration." (Shepard, 2002:75).

The following section of the article focuses on the findings of the study with regard to ideal and real culture, and how this relates to condom use.

\section{Findings \\ An ideal culture of fidelity}

The value of fidelity or faithfulness is part of the ideal culture of most societies. Fidelity is part of the expectations of most dating/courting relationships which later develop into engagements and ultimately marriage, where the exclusivity of the relationship is stressed/formalised. Partners thus promise to concentrate their expressions of erotic/love and sexuality on one person (to be faithful) ${ }^{*}$ (Davidson and Moore, 1992:15). Breach of this norm is considered serious and infidelity often leads to a breakup in the relationship. In a South African study, the male respondents stated that a person should only have one partner and be monogamous (UNAIDS, 2000:59). Trust becomes important as individuals believe that their partners will obey the normative expectation of fidelity.

Given that an ideal culture of faithfulness exists, it is apparent that this is used as a point of reference when negotiating condom use. This study found that the main reasons for the nonuse of condoms is trust.

Trust in this context implies trusting the faithfulness/fidelity of your partner. An appeal is thus made to the ideal culture. Trust was a central idea that ran through the reports of participants in this study. Many women stated that they trusted their partners and therefore did not use condoms. In other cases, men used the question of trust to convince the women not to use condoms. The following responses sum up why condoms were not used:

No, I didn't [use condoms]... it was like ... okay, we trusted each other and he said I was his only girlfriend."

"It was because I trusted him"

"Sometimes /we used condoms], but he didn't prefer them and said that I didn't trust and love him."

"No, he didn't understand them ... he said condoms are for people who like girls and boys and asked if I don't trust him."

The above finding is consistent with other studies that have revealed that the use of condoms have become associated with mistrust and are often not used because they imply mistrust. The use of condoms goes against the ideal culture of fidelity.

To use a condom is to admit that the expectations of ideal culture have been breached. Requests for condom use may be interpreted as distrusting your partner and are viewed as acts of hostility that calls one's partners health and morals in question (LeBeau, Fox, Becker \& Mufune, 2001:66; Oliver, 1996:317). "Condomless sex" on the other hand is seen as a demonstration of trust in one's sexual partner (LeClerc-Madlala, 2001:41).

${ }^{3}$ Even in a polygamous marriage the value of exclusivity is relevants. 


\section{A real culture of infidelity}

"Condomless sex" would not be such a problem if an ideal culture of fidelity was coupled with a real culture of fidelity. Unfortunately a cultural inconsistency exists in this regard and the ideal culture of fidelity is accompanied by a real culture of infidelity. Multi-partnering has become a characteristic of the sexual culture in Southern Africa. In a study in Zimbabwe, Basset (1993:8) found that $80 \%$ of married men had girlfriends in addition to their wives. Along a similar vein, a South African study revealed that although the male respondents said that people are supposed to have only one partner and be monogamous, more than half of the same group of respondents reported having at least one casual partner in the past year (UNAIDS, 2000:59). Multi-partnering also seems to be accepted and even encouraged among teenage boys. In this regard, Tillotson \& Maharaj, (2001: 90) states that the boys "..are also under pressure of peers and social norms that encourage them to engage in multiple sexual relationships to prove their virility ...". The same author found that many boys had more than one girlfriend that they were having sexual relations with.

Infidelity in relationships was also evident in this study as almost all of the participants mentioned infidelity in their relationships. This was often the only thing that marred what appeared to be good relationships. Unfaithfulness was found to occur particularly when men worked out of town, which is in line with the theory that migratory labour has contributed to the spread of HIV (Decosas, 1998 and Hunt, 1989).

“...he was working outside /town/. One day he told about a certain girl who wanted to go out with him. I think he was afraid to tell me the real truth... He didn't want us to tell our parents that we had the virus. He said HIV is not like AIDS and that it can be cured. That's one of the reasons I think I got it from him."

"When men work out ... they should stop sleeping with prostitutes even at the shebeen they must not have sex with any women they come across there."

"...he was doing bad things with other women lhaving affairs], he was doing them outside where I did not see him because sometimes he goes and work outside Bloemfontein."

Yet the women in this study forgave their unfaithful partners. This corresponds with the findings of LeClerc-Madlala (2001:40) who points out that women continue to accept that men have numerous partners and the men seem to regard numerous partners as part of the real culture.

"... he has come back to me and I have accepted him back. He has left that other woman because her husband was fighting with him and I have forgiven him ... but he is still working out sometimes."

“...the only bad thing was that he used to love girls. I would most of the time find him with girls but we used to sort things out."

“.. I think we (men and women) are both the same because we are both unfaithful."

"He disappointed me. I found him with a certain girl, but he begged for forgiveness and said it would never happen again ... but it did continue."

"Yes, I think that every person will end up with this disease because our people are not faithful at all".

In this study it became clear that the issue of ideal versus real culture is relevant when considering condom use. The value of trust (ideal culture) appears to be important in the relationships that were studied. Individuals do not use condoms because they trust their partners. Men ask women if they don't trust them when the women ask for condoms and yet the real culture is something different - a culture of infidelity and a tolerance of infidelity prevails.

\section{Concluding comments}

The ideal situation would be if ideal and real culture were consistent. In this case, condoms would not be necessary except as a contraceptive measure. A real culture of exclusivity and less casual sex could be propagated (this could be from a moral or secular perspective - thus not only for moral but also for health reasons). In the aforementioned instance, ideal culture will guide behaviour and real culture will be consistent bringing greater protection to partners.

However, perhaps it is naïve to think that the real culture of infidelity will change (although some such as Paterson (1996) argue that the HIV epidemic may be the catalyst) given the reality of our society. In this instance, it is necessary to openly acknowledge the real culture of infidelity and that real culture should be the guide when condom use is considered. Perhaps the time has come to insist on condom use and so admit existence of the real culture.

In addition to this, if the real culture of infidelity is acknowledged by all in society, women must have the power to insist on condom use. At present women do not have this power. LeBeau et al. (2001:67) point out that women who are dependent on men for economic support find it difficult to enforce condom use even when they know that their husbands are having extramarital affairs. This raises issues of empowerment of women.

Understanding the ideal real culture clash is one explanation of non-condom use and sheds lights on the behaviour of people in this regard. The "hypocrisy" related to real and ideal culture must be considered and opened up to scrutiny even if it reveals behaviour that in terms of ideal culture, is considered undesirable.

\section{References}

BABBIE, E 1993: The practice of social research (fifth edition). Belmont: Wadsworth.

BASSET, M 1993: Vulnerability to HIV infection: the Zimbabwe experience. AIDS Analysis Africa (Southern Africa Edition) 4(3): 8-10.

DAVIDSON, JK \& MOORE, NB 1992: Marriage and family. USA: Wm. C. Brown. 
DECOSAS, J 1998: Labour migration and HIV epidemics in Africa. AIDS Analysis Africa (Southern Africa Edition) 9(2): 10-11.

DE WET, M; ACKERMANN, L \& CRICHTON, A 2001: InCorrect condom programming in the primary health setting: "A prescription for a disaster"? Curationis, 25(2): 4-13.

GIDDENS, A 1993: Sociology (second edition). Great Britain: Polity Press.

HSRC. 1997: HSRC code of research ethics. Pretoria: HSRC.

HUNT, CW 1989: Migrant labor and sexually transmitted disease: AIDS in Africa. Journal of Health and Social Behaviou, 30 (December): 353-373.

KEY,SW; DE NOON, DJ \& BOYLES, S 1997: Sexually Transmitted Infections: the iceberg under South Africa's AIDS epidemic. Aids Weekly Plus, (22-29 December): 12.

IE BEAU, C; FOX, T; BECKER, H \& MUFUNE, P 2001: Agencies and structures facilitating the transmission of HIV/AIDS in Northern Namibia. Society in Transition, 32(1): 56-68.

LECLERC-MADLALA, $S$ 2001: Demonising women in the era of AIDS: on the relationship between cultural constructions of both HIV/AIDS and femininity. Society in Transition, 32(1): $38-46$.

NEUMAN, WI, 1997: Social research methods: qualitative and quantitative approaches (third edition). Boston: Allyn and Bacon.

OLIVER, LP 1996: Study circles on HIV/AIDS for Africa: Swazi women gain a public voice. Adult Education and Development, 47:317-331.

PATERSON, G 1996: Love in a time of AIDS: women, health and the challenge of HIV. Geneva: WCC.

PESA, JA; SYRE, TR \& FU, Q 1999: Condom use and problem behaviors among sexually active adolescents. Journal of Health Education, 30(2): 120-124.

POPENOE, D 1995: Sociology (tenth anniversary edition). New Jersey: Prentice Hall.

SHEPARD, JM 2002: Sociology (eighth edition). Australia: Wadsworth.

TILLOTSON, J \& MAHARAJ, P 2001: Barriers to HIV/AIDS protective behaviour among African adolescent males in township secondary schools in Durban, South Africa. Society in Transition, 32(1): 83-100.

UNAIDS. 2(900: Report on the global HIV/AIDS epidemic: June 2000 (UNAIDS/(0).13E). Geneva: UNAIDS.

WARREN, M 1997: Condom use in South Africa: facts and fantasies. Aids Scan, 9(3): 4-6.

\section{Acknowledgments}

The authors wish to thank all the HIV positive women who participated in the research project. Thanks also goes to Ms M Mohapi for conducting the interviews. The NRF is also acknowledged for financial assistance. 